\title{
MRJP microsatellite markers in Africanized Apis mellifera colonies selected on the basis of royal jelly production
}

\author{
R.S. Parpinelli ${ }^{1}$, M.C.C. Ruvolo-Takasusuki ${ }^{2}$ and V.A.A. Toledo ${ }^{1}$ \\ ${ }^{1}$ Departamento de Zootecnia, Universidade Estadual de Maringá, \\ Maringá, PR, Brasil \\ ${ }^{2}$ Departamento de Biologia Celular e Genética, \\ Universidade Estadual de Maringá, Maringá, PR, Brasil \\ Corresponding author: V.A.A. Toledo \\ E-mail: abelha.vagner@gmail.com
}

Genet. Mol. Res. 13 (3): 6724-6733 (2014)

Received May 7, 2013

Accepted February 21, 2014

Published August 28, 2014

DOI http://dx.doi.org/10.4238/2014.August.28.16

\begin{abstract}
It is important to select the best honeybees that produce royal jelly to identify important molecular markers, such as major royal jelly proteins (MRJPs), and hence contribute to the development of new breeding strategies to improve the production of this substance. Therefore, this study focused on evaluating the genetic variability of mrjp3, mrjp5, and mrjp 8 and associated allele maintenance during the process of selective reproduction in Africanized Apis mellifera individuals, which were chosen based on royal jelly production. The three loci analyzed were polymorphic, and produced a total of 16 alleles, with 4 new alleles, which were identified at mrjp5. The effective number of alleles at mrjp3 was 3.81. The observed average heterozygosity was 0.4905 , indicating a high degree of genetic variability at these loci. The elevated $F_{\text {IS }}$ values for mrjp3, mrjp5, and mrjp 8 (0.4188, 0.1077 , and 0.2847 , respectively) indicate an excess of homozygotes. The selection of Africanized $A$. mellifera queens for royal jelly production has maintained the mrjp3 $C, D$, and $E$ alleles; although, the $C$ allele occurred at a low frequency. The heterozygosity and $F_{\text {IS }}$ values show that the genetic variability of the queens is decreasing at the analyzed loci, generating an
\end{abstract}


excess of homozygotes. However, the large numbers of drones that fertilize the queens make it difficult to develop homozygotes at mrjp3. Mating through instrumental insemination using the drones of known genotypes is required to increase the efficiency of Africanized A. mellifera-breeding programs, and to improve the quality and efficiency of commercial royal jelly apiaries.

Key words: Major royal jelly proteins; mrjp3; Genetic improvement; Polymorphism; Honeybee queen selection

\section{INTRODUCTION}

Royal jelly is a creamy secretion that is synthesized by the mandibular and hypopharyngeal glands of honeybees, located on the head of nurse worker honeybees and secreted between the 5th and 15th days of worker lifespan (Haydak, 1970; Knecht and Kaatz, 1990; Schmitzová et al., 1998). In general, royal jelly has a milky texture, is highly acidic and nitrogenated, and has a characteristic odor and taste (Chen and Chen, 1995; Melliou and Chinou, 2005; Liu et al., 2008). It has a density of approximately $1.1 \mathrm{~g} / \mathrm{cm}^{3}$ (Lercker et al., 1992) and is partially soluble in water. The viscosity of royal jelly varies with the age of honeybees and water content. Royal jelly is widely known for its complex composition, including various minerals, proteins, amino acids, steroids, phenols, carbohydrates, vitamins, lipids, and other, as yet, unidentified substances (Garcia-Amoedo and Almeida-Muradian, 2007).

Royal jelly is a natural source of essential amino acids, lipids, vitamins, acetylcholine, and other nutrients to the honeybees (Schmitzová et al., 1998), and plays an important role in their reproduction and development. Every female larva of less than 3 days of age may develop into a worker or queen honeybee, depending on the food provided by the nurse honeybees. After 3 days, only the larvae selected by the worker honeybees to become queens receive royal jelly exclusively as a source of food (Winston, 1992; Drapeau et al., 2006).

Among the many products obtained from honeybees, most studies have focused on royal jelly, because of its role as a food source for honeybees and its therapeutic properties. In general, the therapeutic effects of royal jelly have been associated with antibiotic, antifungal, and anti-inflammatory activity, as well as its ability to enhance immune resistance, tissue regeneration, the reduction of plasma cholesterol and triglyceride levels, and antihypertensive activity (Yatsunami and Echigo, 1985, Oka et al., 2001, Matsui et al., 2002; Koshio and Almeida-Muradian, 2003; Münsted and Georgi, 2003, Kohno et al., 2004).

Royal jelly contains several proteins that have molecular weights ranging between 47 and $80 \mathrm{kDa}$ (Hanes and Simúth, 1992). These proteins belong to the group of major royal jelly proteins (MRJPs), which together account for $82-90 \%$ of the total protein content of the jelly. The MRJPs contain relatively large amounts of amino acids, supporting the hypothesis that MRJPs play important roles in the nutrition of honeybees (Schmitzová et al., 1998). A large number of studies performed to identify, characterize, and sequence the MRJPs of Apis mellifera (Klaudiny et al., 1994; Albert et al., 1996; 1999a,b; Schmitzová et al., 1998; Albert and Klaudiny, 2004; Drapeau et al., 2006). Nine proteins from the MRJP family have been identified, of which 5 (MRJP1, MRJP2, MRJP3, MRJP4, and MRJP5) represent about $82 \%$ of the total protein content of royal jelly. The genes encoding these proteins are located on chromosome 11 (Drapeau et al., 2006). Sequencing studies have revealed that mrjp 3 and mrjp 5 contain regions of hypervariable numbers of tandem repeats (VNTRs) of different sizes, sequences, and locations that create high genetic variability and, 
therefore, may be used for genotyping individuals (Schmitzová et al., 1998; Albert et al., 1999b).

Using microsatellite analysis, Albert et al. (1999b) detected high variability at the mrjp3 locus, because of the presence of VNTR regions located in the mrjp3 3rd region. This high genetic variability revealed the value of this gene as a marker for a variety of studies on $A$. mellifera (Beye et al., 1998).

Although the A. mellifera MRJP family has been extensively studied, knowledge remains limited about the possible uses of these molecular markers in population genetic studies or as selective markers associated with royal jelly production. Thus, this study evaluated the genetic variability of the mrjp3, mrjp5, and mrjp8 loci in Africanized A. mellifera producers of royal jelly to identify the molecular markers that are associated with its production. The obtained results are anticipated to provide baseline information on which to develop new strategies to increase the production of royal jelly in commercial apiaries.

\section{MATERIAL AND METHODS}

\section{Collection of biological samples}

The Central Apiary of the Iguatemi Experimental Farm, State University of Maringa, Brazil, provided the Africanized A. mellifera nurse worker honeybees used in this study. In 2006, the 15 queens that produced the highest amounts of royal jelly were selected. From these selected matrices, daughter queens were produced and continue to be maintained in the Central Apiary. The nurse honeybees were collected from seven colonies matrices, placed in Langstroth-type hives, and destined for royal jelly production. The queens from these boxes were naturally mated and evaluated for the production of royal jelly. All queens showed high royal jelly production. Twenty nurse honeybees were collected from each colony, which were selected by their color and age, and extracted from the combs. These honeybees were immediately sacrificed, stored in closed flasks, properly identified, and frozen at $-20^{\circ} \mathrm{C}$ for laboratory analyses.

\section{Extraction and quantification of genomic DNA}

Genomic DNA was extracted from 20 nurse workers from each colony analyzed, totaling 140 individuals. The total DNA extraction method described by Bardakci and Skibinski (1994) was adapted for A. mellifera. The thoraxes were macerated in $400 \mu \mathrm{L}$ lysis buffer (50 $\mathrm{mM}$ Tris- $\mathrm{HCl}, \mathrm{pH} 8.0,50 \mathrm{mM}$ EDTA, $\mathrm{pH} 8.0,100 \mathrm{mM} \mathrm{NaCl}, 1 \%$ SDS) and $10 \mu \mathrm{L}$ proteinase $\mathrm{K}(5 \mu \mathrm{g} / \mu \mathrm{L})$. The samples were maintained at $55^{\circ} \mathrm{C}$ for $4 \mathrm{~h}$. DNA was purified with a solution of phenol:chloroform:isoamyl alcohol (25:24:1) and chloroform:isoamyl alcohol (24:1). From the recovered volume, DNA was precipitated using $3 \mathrm{M}$ sodium acetate and cold absolute ethanol at a ratio of $0.25: 2.5$ and incubated overnight at $-20^{\circ} \mathrm{C}$. The precipitated DNA was separated by centrifugation at 10,300 $\mathrm{g}$ for $10 \mathrm{~min}$, resuspended in TE buffer (10 mM Tris, 1 mM EDTA, $\mathrm{pH} 8.0)$, and treated with $3 \mu \mathrm{L}$ RNase $(10 \mu \mathrm{g} / \mathrm{mL})$.

DNA integrity and concentration were verified on $0.8 \%$ agarose gels with $1 \mathrm{X}$ TAE buffer (0.04 M Tris-acetate, $0.001 \mathrm{M}$ EDTA, $\mathrm{pH}$ 8.0). The amount of DNA in each sample was estimated by comparison with known and graded concentrations of standard DNA ( $\lambda$ phage). The agarose gels were stained with $0.5 \mu \mathrm{g} / \mathrm{mL}$ ethidium bromide solution. The DNA bands were then visualized with UV light, and the images were captured with an L-PIX HE (Loccus Biotecnologia, Brazil), molecular imaging system. 


\section{Polymerase chain reaction (PCR) amplification}

PCR was performed using synthesized specific primers to amplify the repetitive regions of mrjp3 (Albert et al., 1999b) and mrjp5 (Albert et al., 1999a), and to amplify the mrjp8 locus (Klaudiny et al., 1994): mrjp3 (forward: ATG TAA TTT TGA AGA ATG AAC TTG; reverse: TGT AGA TGA CTT AAT GAG AAA CAC); $m r j p 5$ (forward: AGA CTC TTC AAA CGG TCG TTG C; reverse: CTG TAA TTT CAT ACT TAA AGC CAT); and mrjp8 (forward: TTG CGA AGT GAA TGG ATC; reverse: TTA TTT TTG GCA ACC ACT TCG).

In a reaction volume of $20 \mu \mathrm{L}$, we used $1 \mathrm{X}$ Tris- $\mathrm{KCl}$ buffer $(20 \mathrm{mM}$ Tris-HCl, $\mathrm{pH}$ 8.4, $50 \mathrm{mM} \mathrm{KCl}$ ), $0.5 \mu \mathrm{M}$ of each primer, $0.1 \mathrm{mM}$ of each dNTP, and $1 \mathrm{U}$ Platinum Taq DNA Polymerase (Invitrogen). Optimizing the PCRs, we adopted specific concentrations of $\mathrm{MgCl}_{2}$ and DNA template according to the primer that was used (Table 1). Thus, for amplification with the mrjp3, mrjp5, and mrjp 8 primers, the $\mathrm{MgCl}_{2}$ concentrations adopted were $1.7,1.5$, and $3.0 \mathrm{M} / \mathrm{L}$, respectively. The concentration of the DNA template for the mrjp 3 primer was $10 \mathrm{ng} / \mu \mathrm{L}$, and was $20 \mathrm{ng} / \mu \mathrm{L}$ for the $m r j p 5$ and $m r j p 8$ primers.

Table 1. PCR conditions for the amplification of MRJP loci from Africanized Apis mellifera honeybees.

\begin{tabular}{|c|c|c|c|c|c|c|}
\hline Parameter & mrjp3 & & mrjp5 & & mrjp 8 & \\
\hline $\mathrm{MgCl}_{2}(\mathrm{M} / \mathrm{L})$ & 1.7 & & 1.5 & & 3.0 & \\
\hline DNA (ng/ $\mu \mathrm{L})$ & 10.0 & & 20.0 & & 20.0 & \\
\hline PCR conditions & $\mathrm{T}\left({ }^{\circ} \mathrm{C}\right)$ & Time & $\mathrm{T}\left({ }^{\circ} \mathrm{C}\right)$ & Time & $\mathrm{T}\left({ }^{\circ} \mathrm{C}\right)$ & Time \\
\hline Denaturation & 94 & $30 \mathrm{~s}$ & 94 & $30 \mathrm{~s}$ & 94 & $50 \mathrm{~s}$ \\
\hline Annealing & 54 & $30 \mathrm{~s}$ & 54 & $30 \mathrm{~s}$ & 50 & $50 \mathrm{~s}$ \\
\hline Extension & 72 & $1 \mathrm{~min}$ & 72 & $1 \mathrm{~min}$ & 72 & $100 \mathrm{~s}$ \\
\hline
\end{tabular}

PCRs were performed in a Techne TC-512 thermocycler (Keison, UK), and the conditions for the amplification with the mrjp3 and mrjp 5 primers were based on Albert and Schmitz (2002). The process started with an initial denaturation step of $2 \mathrm{~min}$ at $94^{\circ} \mathrm{C}$, followed by 30 cycles of $30 \mathrm{~s}$ at $94^{\circ} \mathrm{C}, 30 \mathrm{~s}$ at $54^{\circ} \mathrm{C}$, and $1 \mathrm{~min}$ at $72^{\circ} \mathrm{C}$. The reaction was completed with a final extension step of $10 \mathrm{~min}$ at $72^{\circ} \mathrm{C}$. For DNA amplification using the mrjp 8 primer, the PCR conditions were based on Albert and Klaudiny (2004). In brief, an initial denaturation step of 5 min at $94^{\circ} \mathrm{C}$ was used, followed by 35 cycles of $50 \mathrm{~s}$ at $94^{\circ} \mathrm{C}, 50 \mathrm{~s}$ at $50^{\circ} \mathrm{C}$, and $100 \mathrm{~s}$ at $72^{\circ} \mathrm{C}$. The reaction was completed with a final extension step of $10 \mathrm{~min}$ at $72^{\circ} \mathrm{C}$.

The amplification products were separated on $2 \%$ agarose gels prepared with $0.5 \mathrm{X}$ TBE buffer ( $44.5 \mathrm{mM}$ Tris, $44.5 \mathrm{mM}$ borate, and $1 \mathrm{mM}$ EDTA). Preparing the agarose gel, we used 50\% common agarose and 50\% MetaPhor agarose (Cambrex). The separation was performed at $60 \mathrm{~V}$ for $5 \mathrm{~h}$. The gels were stained and visualized as described in the section for the extraction and quantification of genomic DNA, using a100-bp DNA ladder (Invitrogen) to determine the sizes of the amplified alleles.

\section{Data analysis}

The molecular data analyses involved the interpretation of the amplified fragments of genomic DNA. F statistics $\left(F_{\mathrm{IS}}, F_{\mathrm{IT}}\right.$, and $\left.F_{\mathrm{ST}}\right)$, Nei $(1973) \mathrm{H}$ statistic, and the effective number of alleles were estimated using the POPGENE 1.31 software (Yeh et al., 1999). 


\section{RESULTS}

The mrjp3, mrjp5, and mrjp 8 loci encoded 16 polymorphic alleles (Table 2). The effective number of alleles was 3.81 for $m r j p 3,3.13$ for $m r j p 5$, and 2.56 for $m r j p 8$, with an average value of 3.17 alleles. Figure 1 presents the amplified fragments of the 3 loci analyzed and their respective alleles.

Table 2. MRJP loci from Africanized Apis mellifera producers of royal jelly, showing the size of each allele in $\mathrm{bp}$ and the allelic frequencies (F) obtained from the seven colonies analyzed.

\begin{tabular}{|c|c|c|c|c|c|c|}
\hline \multirow[t]{2}{*}{ Allele } & \multicolumn{2}{|c|}{ mrjp3 } & \multicolumn{2}{|c|}{ mrjp5 } & \multicolumn{2}{|c|}{ mrjps } \\
\hline & $\mathrm{bp}$ & $\mathrm{F}$ & bp & $\mathrm{F}$ & $\mathrm{bp}$ & $F$ \\
\hline$A$ & $410^{*}$ & - & $570 *$ & - & $360^{*}$ & 0.0143 \\
\hline$B$ & $460^{*}$ & - & $590 *$ & - & $370^{*}$ & 0.1786 \\
\hline$C$ & $480^{*}$ & 0.0321 & $610 *$ & - & $390 *$ & 0.5321 \\
\hline$D$ & $510^{*}$ & 0.3357 & $620^{*}$ & 0.2643 & $420^{*}$ & 0.2750 \\
\hline$E$ & $530^{*}$ & 0.3107 & $680 *$ & 0.4393 & - & - \\
\hline$F$ & $580^{*}$ & 0.1786 & $720 *$ & 0.2357 & - & - \\
\hline$G$ & $610^{*}$ & 0.1429 & - & - & - & - \\
\hline$H$ & - & - & 650 & 0.0036 & & - \\
\hline$I$ & - & - & 750 & 0.0250 & - & - \\
\hline$J$ & - & - & 780 & 0.0143 & - & - \\
\hline$K$ & _- & - & 800 & 0.0179 & _- & - \\
\hline
\end{tabular}

*Described by Baitala et al. (2010).

A

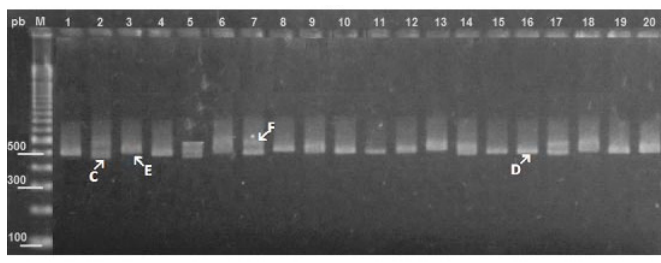

B

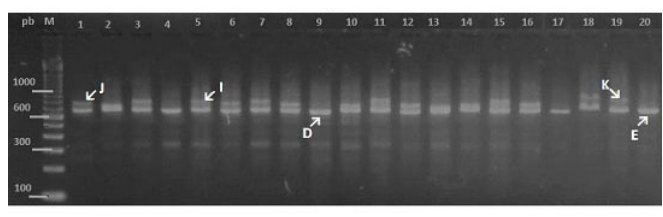

C

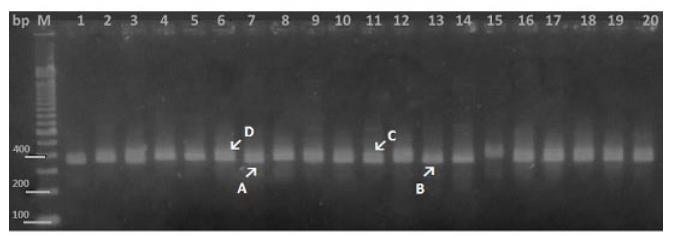

Figure 1. Electrophoresis profile of MRJP loci of the Africanized Apis mellifera honeybees. A. Amplified fragments of the mrjp3 locus. B. Amplified fragments of the mrjp5 locus. C. Amplified fragments of the mrjp 8 locus. M = DNA molecular weight marker (DNA Ladder, Invitrogen). The arrows and letters indicate the alleles identified for each locus.

The values obtained by the $\chi^{2}$ test are presented in Table 3 . All seven of the colonies analyzed showed deviations from the Hardy-Weinberg equilibrium (HWE) at the mrjp 3 locus. Five of the colonies showed deviations at the mrjp5 locus, while three of the colonies showed deviations at the mrjp 8 locus. 
Table 3. Chi-squared $\left(\chi^{2}\right)$ test to verify the Hardy-Weinberg equilibrium of the MRJP loci in seven colonies of Africanized Apis mellifera.

\begin{tabular}{|c|c|c|c|}
\hline Colony & mrjp3 & mrjp5 & mrjp 8 \\
\hline \multirow[t]{2}{*}{$\overline{1}$} & $\begin{array}{l}\chi^{2}=22.41 \\
\text { d.f. }=1\end{array}$ & $\begin{array}{l}\chi^{2}=42.88 \\
\text { d.f. }=10\end{array}$ & $\begin{array}{l}\chi^{2}=1.91 \\
\text { d.f. }=3\end{array}$ \\
\hline & & $\mathrm{P}=0.000005$ & $\mathrm{P}=0.590386$ \\
\hline \multirow[t]{2}{*}{2} & $\begin{array}{l}\chi^{2}=25.92 \\
\text { d.f. }=6\end{array}$ & $\begin{array}{l}\chi^{2}=5.30 \\
\text { d.f. }=1\end{array}$ & $\begin{array}{l}\chi^{2}=8.28 \\
\text { d.f. }=3\end{array}$ \\
\hline & $\mathrm{P}=0.000230$ & $\mathrm{P}=0.021285$ & $\mathrm{P}=0.040488$ \\
\hline \multirow[t]{2}{*}{3} & $\begin{array}{l}\chi^{2}=15.30 \\
\text { d.f. }=6\end{array}$ & $\begin{array}{l}\chi^{2}=3.73 \\
\text { d.f. }=3\end{array}$ & $\begin{array}{l}\chi^{2}=2.95 \\
\text { d.f. }=6\end{array}$ \\
\hline & $\mathrm{P}=0.01801$ & $\mathrm{P}=0.291503$ & $\mathrm{P}=0.814983$ \\
\hline \multirow[t]{2}{*}{4} & $\begin{array}{l}\chi^{2}=12.31 \\
\text { d.f. }=3\end{array}$ & $\begin{array}{l}\chi^{2}=18.99 \\
\text { d.f. }=10\end{array}$ & $\begin{array}{l}\chi^{2}=2.32 \\
\text { d.f. }=3\end{array}$ \\
\hline & $\mathrm{P}=0.006387$ & $\mathrm{P}=0.040307$ & $\mathrm{P}=0.507901$ \\
\hline \multirow[t]{2}{*}{5} & $\chi^{2}=13.78$ & $\chi^{2}=3.10$ & $\chi^{2}=0.43$ \\
\hline & $\begin{array}{l}\text { d.f. }=3 \\
P=0.003207\end{array}$ & $\begin{array}{l}\text { d.f. }=6 \\
P=0.795217\end{array}$ & $\begin{array}{l}\text { d.f. }=1 \\
P=0.509893\end{array}$ \\
\hline \multirow[t]{3}{*}{6} & $\chi^{2}=12.00$ & $\chi^{2}=1.85$ & $\chi^{2}=3.27$ \\
\hline & d.f. $=3$ & d.f. $=10$ & d.f. $=1$ \\
\hline & $\mathrm{P}=0.007364$ & $\mathrm{P}=0.997351$ & $\mathrm{P}=0.070525$ \\
\hline \multirow[t]{2}{*}{7} & $\chi^{2}=5.20$ & $\chi^{2}=11.65$ & $\chi^{2}=3.52$ \\
\hline & $\begin{array}{l}\text { d.f. }=3 \\
P=0.157724\end{array}$ & $\begin{array}{l}\text { d.f. }=3 \\
P=0.0088686\end{array}$ & $\begin{array}{l}\text { d.f. }=1 \\
P=0.060373\end{array}$ \\
\hline
\end{tabular}

d.f. $=$ degrees of freedom; $\mathrm{P}=$ probability value. $\mathrm{P}>0.05$ is in Hardy-Weinberg equilibrium. $\mathrm{P}<0.05$ is not in Hardy-Weinberg equilibrium.

The average heterozygosity value observed for the three loci analyzed was 0.4905 , indicating a high degree of genetic diversity for the samples analyzed (Table 4 ). The $F_{\text {IS }}$ values presented in Table 5 indicate that the colonies analyzed had an excess of homozygotes.

Table 4. Observed $\left(H_{\mathrm{O}}\right)$ and expected heterozygosity $\left(H_{\mathrm{E}}\right)$ values of MRJP loci from the analyzed colonies of Africanized Apis mellifera.

\begin{tabular}{lcc}
\hline Locus & $H_{\mathrm{O}}$ & $H_{\mathrm{E}}$ \\
\hline mrjp3 & 0.4286 & 0.7285 \\
mrjp5 & 0.6071 & 0.6848 \\
mrjp8 & 0.4357 & 0.6113 \\
Mean & 0.4905 & 0.6749 \\
Standard deviation & 0.1011 & 0.0593 \\
\hline
\end{tabular}

Table 5. Fixation indices $\left(F_{\text {IS }}\right)$ for the MRJP loci of the Africanized Apis mellifera royal jelly producers.

\begin{tabular}{lccc}
\hline Allele/locus & mrjp3 & mrjp5 & mrjp8 \\
\hline$A$ & - & - & -0.0145 \\
$B$ & - & - & 0.3183 \\
$C$ & 0.4260 & - & 0.1250 \\
$D$ & 0.3274 & 0.1918 & 0.4805 \\
$E$ & 0.6165 & 0.1155 & - \\
$F$ & 0.5617 & 0.0484 & - \\
$G$ & 0.0667 & - & - \\
$H$ & - & -0.0036 & - \\
$I$ & - & -0.0256 & - \\
$J$ & - & -0.0145 & - \\
$K$ & - & -0.0182 & - \\
Total & 0.4188 & 0.1077 & 0.2847 \\
\hline
\end{tabular}


Table 6 shows the genotypes of the queens and the probable drones that produced the worker honeybees for this study. The drones made a significant contribution to the genetic variability in the analyzed MRJP loci, as the queens were fertilized by a minimum of two and a maximum of five drones.

\begin{tabular}{|c|c|c|c|c|c|c|}
\hline \multirow[b]{2}{*}{ Colony } & \multicolumn{2}{|c|}{ mrjp3 } & \multicolumn{2}{|c|}{ mrjp5 } & \multicolumn{2}{|c|}{ mrjp8 } \\
\hline & Queen & Drone & Queen & Drone & Queen & Drone \\
\hline 1 & $D E$ & $D ; E$ & $D E$ & $D ; E ; K ; I ; J$ & $C D$ & $A ; C ; D$ \\
\hline 2 & $D E$ & $E ; F ; G$ & $E F$ & $E ; F$ & $B C$ & $B ; C ; D$ \\
\hline 3 & $D E$ & $D ; E ; F ; G$ & $D E$ & $D ; E ; F$ & $B C$ & $A ; B ; C ; D$ \\
\hline 4 & $C E$ & $C ; E ; G$ & $D E$ & $D ; E ; F ; I ; J$ & $B C$ & $B ; C$ \\
\hline 5 & $E F$ & $D ; E ; F$ & $D E$ & $D ; E ; F ; I$ & $B C$ & $B ; C$ \\
\hline 6 & $D E$ & $C ; D ; E ; F$ & $D E$ & $D ; E ; F ; H ; J$ & $C D$ & $C ; D$ \\
\hline 7 & $F G$ & $E ; F ; G$ & $E F$ & $D ; E ; F$ & $C D$ & $C ; D$ \\
\hline
\end{tabular}

\section{DISCUSSION}

Queen selection for royal jelly production has been kept in apiary at Universidade Estadual de Maringá, Brazil, since 2003 hence Baitala et al. (2010) developed an initial study for selection of Africanized A. mellifera queens' royal jelly producers. After the period of 3 years, high degree of genetic variability was detected for MRJP loci analyzed, but it has decreased with the selection time. Moreover, alleles mrjp $3 C, D$ and $E$, initially proposed as important for the production of royal jelly, continue to occur in hive matrices.

Initially in 2010 were identified seven alleles of mrjp3, with sizes of $410 \mathrm{bp}(A), 460$ bp (B), $480 \mathrm{bp}(C), 510 \mathrm{bp}(D), 530 \mathrm{bp}(E), 580 \mathrm{bp}(F)$, and $610 \mathrm{bp}(G)$. The mrjp5 locus had 6 alleles, with sizes of $570 \mathrm{bp}(A), 590 \mathrm{bp}(B), 610 \mathrm{bp}(C), 620 \mathrm{bp}(D), 680 \mathrm{bp}(E)$, and $720 \mathrm{bp}(F)$. In the present study, we detected different allelic compositions of mrjp 3 and $m r j p 5$ compared to those observed by Baitala et al. (2010). For instance, the $A$ and $B$ alleles of $m r j p 3$ that were previously detected by Baitala et al. (2010) were not found in the queens that were analyzed in the current study (Table 2). At the mrjp 5 locus, alleles $D, E$, and $F$ were detected in this study, together with four new alleles, called $H$ (650 bp), $I$ (750 bp), $J$ (780 bp), and $K$ (800 bp). Therefore, it will be necessary to sequence these alleles and compare the results with sequences to determine whether they have been previously described, or whether they are new alleles. The current study found the same alleles in mrjp 8 as those described by Baitala et al. (2010) (Table 2).

The $D$ and $E$ alleles at the mrjp 3 locus had the highest frequencies $(0.3357$ and 0.3107 , respectively) (Table 2). This observation indicates that these alleles are being maintained in the queen selection for the production of royal jelly. Only the $C$ allele, which also has the potential as a marker for royal jelly production, was rare (0.0321). The effective number of alleles for mrjp3 (3.81) shows that the alleles that are being selected for at this locus $(C, D$, and $E)$ are probably those that make the greatest contributions to royal jelly production.

HWE was tested, as shown in Table 3. The results indicate that the mrjp 3 locus is under selection. HWE was not observed at mrjp 3 in any of the seven colonies analyzed. The mrjp 5 and mrjp 8 loci are probably not under selection, as HWE was observed in colonies 3, 5, and 6 at mrjp5 and in colonies 2, 6, and 7 at mrjp 8 (Table 3). Based on these results, mrjp5 and mrjp 8 are not 
under strong selection, whereas mrjp 3 is. Future studies should continue to examine the mrjp 3 and mrjp5 genotypes in relation to royal jelly production. The development of studies at the genetic or proteomic level is also required to identify how these proteins contribute to royal jelly production.

The estimated heterozygosity values indicate that there is a high degree of polymorphism at the three loci analyzed (Table 4 ), whereas the $F_{\text {IS }}$ values show that the three loci have an excess of homozygotes (Table 5). Only the $H, I, J$, and $K$ alleles of $m r j p 5$ and the $A$ allele of the mrjp 8 locus showed no deficiency of heterozygotes. Baitala et al. (2010) obtained values of average heterozygosity of 0.5827 to $m r j p 3$, mrjp 5 and $m r j p 8$, higher than the value obtained in the present study that was 0.4905 . In the present study, the average heterozygosity was 0.4905 . Therefore, selection for MRJP alleles and for royal jelly production seems to be leading to homozygosity at these loci, particularly at mrjp 3 , which had the lowest heterozygosity value, 0.4286 (Table 4).

De la Rúa et al. (2001) also evaluated the heterozygosity values of honeybees under selection for the production of royal jelly. In this previous study, the average heterozygosity observed for eight microsatellite loci of A. mellifera from the Canary Islands ranged from 0.312 to 0.432 . The relatively higher heterozygosity values observed in the current study might be explained by the number of drones that mated with the selected queens (Table 6). During natural mating, A. mellifera females copulate with up to 17 drones, enhancing the genetic variability. In the seven queens analyzed here, genes from two to five drones per queen were identified (Table 6). Even under natural mating conditions, the genetic characteristics of the queens are shifting towards homozygosity, as indicated by the elevated values of $F_{\text {IS }}$. mrjp 3 had the highest $F_{\text {IS }}$ values, demonstrating that the selective process is maintaining the alleles of interest for royal jelly production.

Reproductive selection alters the genetic characteristics of a given population, which is influenced by the process of gene transfer from generation to generation (Falconer, 1987). Moreover, it is beneficial for a population to maintain a certain degree of genetic variability, because polymorphisms within a population result in a greater ability to respond to selective pressures, especially in animal breeding programs for consumption purposes (Page and Kerr, 1991). In recent years, it has become necessary to use instrumental insemination, each female is fertilized with the semen from a single drone. This method is important because natural mating promotes increased genetic variability, introducing new alleles that are not of interest for directed genetic improvement. The high heterozygosity values detected in the current study are indicative of this artificial interference, and correspond to the alleles introduced by the drones (Table 6).

The maintenance of Africanized A. mellifera matrices, which are the best producers of royal jelly, will facilitate the establishment of a genetic improvement program, which would enable queens to be supplied to commercial apiaries and would improve the value of this commercial product. The selection of Africanized A. mellifera queens has maintained the $C, D$, and $E$ alleles at the mrjp 3 locus, with the $D$ and $E$ alleles showing the highest frequencies in the queens analyzed in this study. In conclusion, instrumental insemination with a single drone is necessary to obtain homozygous queens for the mrjp 3 alleles of interest, and to establish a breeding program of Africanized A. mellifera that maximizes royal jelly production.

\section{ACKNOWLEDGMENTS}

The authors thank CNPq (National Council for Scientific and Technological Development; Process \#479329/2009-5, \#303345/2008-0, and \#308283/2011-2) for providing financial support. 


\section{REFERENCES}

Albert S and Schmitz J (2002). Characterization of major royal jelly protein-like DNA sequences in Apis dorsata. J. Apic. Res. 41: 75-85.

Albert S and Klaudiny J (2004). The MRJP/YELLOW protein family of Apis mellifera: identification of new members in the EST library. J. Insect Physiol. 50: 51-59.

Albert S, Klaudiny J and Simúth J (1996). Newly discovered features of the updated sequence of royal jelly protein RJP571; longer repetitive region on C-terminus and homology to Drosophila melanogaster yellow protein. J. Apic. Res. 35: 63-68.

Albert S, Bhattacharya D, Klaudiny J, Schmitzova J, et al. (1999a). The family of major royal jelly proteins and its evolution. J. Mol. Evol. 49: 290-297.

Albert S, Klaudiny J and Simuth J (1999b). Molecular characterization of MRJP3, highly polymorphic protein of honeybee (Apis mellifera) royal jelly. Insect Biochem. Mol. Biol. 29: 427-434.

Baitala TV, Faquinello P, Toledo VAA, Mangolin CA, et al. (2010). Potential use of major royal jelly proteins (MRJPs) as molecular markers for royal jelly production in Africanized honeybee colonies. Apidologie 41: 160-168.

Bardakci F and Skibinski DO (1994). Application of the RAPD technique in tilapia fish: species and subspecies identification. Heredity 73 (Pt 2): 117-123.

Beye M, Neumann P, Schmitzova J, Klaudiny J, et al. (1998). A simple, non-radioactive DNA fingerprinting method for identifying patrilines in honeybee colonies. Apidologie 29: 255-263.

Chen LC and Chen SY (1995). Changes in protein components and storage stability of royal jelly under various conditions. Food Chem. 54: 195-200.

De la Rúa P, Galián J, Serrano J and Moritz RF (2001). Genetic structure and distinctness of Apis mellifera L. populations from the Canary Islands. Mol. Ecol. 10: 1733-1742.

Drapeau MD, Albert S, Kucharski R, Prusko C, et al. (2006). Evolution of the Yellow/Major Royal Jelly Protein family and the emergence of social behavior in honey bees. Genome Res. 16: 1385-1394.

Falconer DS (1987). Introduction to Quantitative Genetics. UFV, Viçosa.

Garcia-Amoedo LH and Almeida-Muradian LB (2007). Physicochemical composition of pure and adulterated royal jelly. Quim. Nova 30: 257-259.

Hanes J and Simúth J (1992). Identification and partial characterization of the major jelly protein of the honeybee (Apis mellifera L.). J. Apic. Res. 31: 22-26.

Haydak MH (1970). Honey bee nutrition. Аnпи. Rev. Entomol. 15: 143-156.

Klaudiny J, Hanes J, Kulifajova J, Albert S, et al. (1994). Molecular cloning of two cDNAs from the head of the nurse honey bee (Apis mellifera L.) coding for related proteins of royal jelly. J. Apic. Res. 33: 105-111.

Knecht D and Kaatz HH (1990). Patterns of larval food production by hypopharyngeal glands in adult worker honey bees. Apidologie 21: 457-458.

Kohno K, Okamoto I, Sano O, Arai N, et al. (2004). Royal jelly inhibits the production of proinflammatory cytokines by activated macrophages. Biosci. Biotechnol. Biochem. 68: 138-145.

Koshio S and Almeida-Muradian LB (2003). Application of HPLC to measure 10-hydroxy-2-decenoic acid in pure royal jelly and Brazilian honey with royal jelly. Quim. Nova 26: 670-673.

Lercker G, Caboni MF, Vecchi MA, Sabatini AG, et al. (1992). Characterization of the major constituents of royal jelly. Apicultura 8: 11-21.

Liu JR, Yang YC, Shi LS and Peng CC (2008). Antioxidant properties of royal jelly associated with larval age and time of harvest. J. Agric. Food Chem. 56: 11447-11452.

Matsui T, Yukiyoshi A, Doi S, Sugimoto H, et al. (2002). Gastrointestinal enzyme production of bioactive peptides from royal jelly protein and their antihypertensive ability in SHR. J. Nutr. Biochem. 13: 80-86.

Melliou E and Chinou I (2005). Chemistry and bioactivity of royal jelly from Greece. J. Agric. Food Chem. 53: 8987-8992.

Münsted K and Georgi RV (2003). Royal jelly - a miraculous product from the bee hive? Am. Bee J. 143: 647-650.

Nei M (1973). Analysis of gene diversity in subdivided populations. Proc. Natl. Acad. Sci. U. S. A. 70: 3321-3323.

Oka H, Emori Y, Kobayashi N, Hayashi Y, et al. (2001). Suppression of allergic reactions by royal jelly in association with the restoration of macrophage function and the improvement of Th1/Th2 cell responses. Int. Immunopharmacol. 1: $521-532$.

Page RE and Kerr WE (1991). Honey Bee Genetics and Breeding. In: The “African” Honey Bee (Spivak M, Fletcher DJC and Breed MD, eds.). Westview Press, Boulder, 157-186.

Schmitzová J, Klaudiny J, Albert S, Schroder W, et al. (1998). A family of major royal jelly proteins of the honeybee Apis mellifera L. Cell Mol. Life Sci. 54: 1020-1030. 
Winston ML (1992). The biology and management of Africanized honey bees. Ann. Rev. Entomol. 37: 173-193.

Yatsunami K and Echigo T (1985). Antibacterial activity of royal jelly. Bull. Fac. Agric. 25: 13-22.

Yeh FC, Boyle TYZ and Xiyan JM (1999). POPGENE Version 1.31: Microsoft Windows-Based Freeware for Population Genetic Analysis. University of Alberta and Center for International Forestry Research, Edmonton. 